

\title{
THE EXTENT OF THE APPLICABILITY OF THE PRINCIPLE OF FAIR HEARING IN ADMINISTRATIVE ADJUDICATION IN NIGERIA
}

\author{
Reginald Anosike Uzoechi, Esq. *
}

\begin{abstract}
This paper considers and examines the extent of the applicability of the principles of fair hearing in administrative adjudication in Nigeria. The paper holds the view that administrative adjudicatory bodies are compulsorily bound by the principles of fair hearing as most of their functions affect the rights and obligations of individuals appearing before them. Bearing in mind that these principles of fair hearing (and others ancillary to them) are however not straight jacket principles, hence this paper. In achieving this purpose, the paper adopts the thematic and doctrinal methods of research. The paper adopts the analytical, critical, expository and comparative methods of presentation, with copious reference to the 1999 Constitution of the Federal Republic of Nigeria; Textbooks on Constitutional and Administrative Law and Human Rights Law; Statute books; Law Reports (Case Laws); National Assembly Gazettes, Local and International Journals as primary and secondary sources of material on the subject-matter.
\end{abstract}

Keywords: Administrative Adjudication, Administrative Tribunal, Fair Hearing, Human Rights, Right to Fair Hearing, Principles of Natural Justice.

\section{Introduction}

The increase in the regulatory powers of public authorities provides the opportunity for the application of the principles of natural justice in disciplinary roles. ${ }^{1}$ Delegation of powers has become a convenient tool to meet up with the responsibilities of the modern complex nature of governance warranting delegated legislation and empowering administrative bodies take up some of the traditional judicial functions of the courts and sit as Tribunals, Panels, or Commissions of Inquiry and etc. These administrative adjudicatory bodies adjudicate on any matter brought before them; make determinations on rights and obligations of individuals and parties before them and perform such other functions as may be assigned to them. ${ }^{2}$

As these administrative tribunals assume quasi-judicial responsibilities to determine issues of rights and obligations of individuals brought before them; just like the regular courts, these administrative tribunals and adjudicatory bodies are bound by the principles of natural justice (fair hearing) in the determination of the rights and obligations of

\footnotetext{
*Reginald Anosike Uzoechi, Esq. LLM, BL, Assistant Lecturer, Department of Public and Private Law, Faculty of Law, Nnamdi Azikiwe University, Awka, PhD Candidate, Faculty of Law, Nnamdi Azikiwe University, Awka, Nigeria.reginalduzoechi@nigerianbar.ng or reeginalduzoechi@yahoo.com.

1 L Atsegbua, Administrative Law, An Introductory Text, (3 ${ }^{\text {rd }}$ edn, Benin City: Filters Lane Publishers, 2010) p. 115.

2 E Malemi, Administrative Law (3 ${ }^{\text {rd }}$ edn, Lagos: Princeton Publishing Co., 2008) p.181.
} 
individuals appearing before them. ${ }^{3}$ This study examines the extent of the applicability of the principles of fair hearing in such administrative adjudication in Nigeria.

\section{The Principle of Fair Hearing}

The principles or doctrine of fair hearing in its statutory and constitutional sense is derived from the principles of Natural Justice and its twin pillars, namely audi alterem partem, which means "hear the other side", and nemo judex in causa sua, which means "no one should be a judge in his own cause". The principle is of general application not only in Nigeria, but also in other Common Law countries to the extent that a presumption has now evolved that whenever any power is conferred by any statute on any authority or body to make a determination, such a determining power shall be exercised judicially and in accordance with the rules of natural justice. Therefore, a breach or otherwise of fair hearing is regarded or treated as very fundamental and a sine qua non to any proceedings, hearing or a trial which is subject to an adjudicatory process. ${ }^{4}$

Consequently, any proceedings conducted in breach of a party's right to fair hearing, no matter how well conducted would be rendered a nullity. ${ }^{5}$ In Inogha Mfa \& Ors. v Mfa Inongha ${ }^{6}$ the Supreme Court, Per Kekere-Ekun, J.S.C., observed that:

The law is indeed settled that fair hearing within the meaning of section 36 (1) of The Constitution of the Federal Republic of Nigeria, 1999, means a trial or hearing conducted according to all legal rules formulated to ensure that justice is done to the parties. It requires the observation of the twin pillars of the rules of natural justice, namely, audi alterem partem and nemo judex in caus sua. These rules, the obligation to hear the other side of the dispute or the right of a party in dispute to be heard, is basic and fundamental a principle of our adjudicatory system in the determination of disputes that it cannot be compromised on any ground... the effect of denial of fair hearing is trite in law. In other words, once there is a breach of the right of fair hearing, the whole proceedings in the course of which the breach occurred and the decision arrived at by the court, becomes a nullity.

\footnotetext{
3 Constitution of Nigeria of the Federal Republic of Nigeria 1999, s. 36 (1) (hereinafter "1999 Constitution of Nigeria); Ridge $v$ Balwin (1964) A.C. 40.

4 Tamti v Nigerian Custom Service Board [2009] 7 NWLR (pt.1141) 636 CA

5 Tsokwa Motors (Nig.) Ltd. v UBA PLC (2008) All FWLR (pt. 403) 1240 @ 1255, paras A-B; Abubakar Audu v FRN (2013) 53 NSCOR 456@469.

6 (2014) LPELR-22010 (SC); see also Chime v Onyia [2009] 2 NWLR (pt.) 18 CA.
} 
The principle of natural justice is linked to Natural Law, but historically, the principle of natural justice has its foundation from Genesis $3: 9-13 ; 16-19,{ }^{7}$ where the Scripture reports that Lord God did not condemn Adam \& Eve without first giving them an opportunity of being heard. ${ }^{8}$

The natural law concept or principle of fair hearing, which is of course, fundamental and bedrock of adjudication or administrative inquiry is as enshrined in s. 36 of the 1999 Constitution of Nigeria, the Nation's grundnorm so deep rooted there is no escape from. ${ }^{9}$ The principle's constitutional impetus reads thus:

In the determination of his civil rights and obligations including any question or determination by or against any government or authority, a person shall be entitled to fair hearing within a reasonable time by a court or a tribunal established by the law and constituted in such a manner as to secure its independence and impartiality.

These twin pillars form the bedrock of the concept of fair hearing, even as extended to administrative adjudication. This is because justice is fairness. To achieve justice, there should be to each and every party appearing before a Court or Tribunal an opportunity to appear without fear or favour, affection or ill will. Denial of justice is bad and outrageous, so much so that such denial inflicts pains, grief and untold hardship upon those who tend to naturally resort to and rely on administration of justice in the pursuit or defence of their inalienable rights. ${ }^{10}$

What follows here is a discussion of these twin pillars of fair hearing, as it is applicable in administrative adjudication in various administrative institutions like the disciplinary committees of professional bodies, corporate establishments, civil/public service and even educational institutions. We shall also take a look at the classifications of administrative powers for the purposes of fair hearing, and some demerits of administrative adjudication.

We will take a tour through these two pillars of fair hearing, one after the other, so as to show how these administrative tribunals comply with their tenets, and how noncompliance of any of those influences the regular courts in the cause of judicial review.

\footnotetext{
7 The New King James Version.

8 Kayode Eso, Thoughts on Human Rights \& Education, (Ibadan: St. Paul's Publishing House, 2008) p.267.

9 Judicial Service Commission of Cross Rivers State v Young [2013] 11 NWLR (pt. 1364) 1

10 Atsegbua, op cit, p.139.
} 


\subsection{Audi alteram partem: Hear the other Side}

This is the part of fair hearing which dictates that before any administrative tribunal could reach a decision affecting any individual's rights or obligations, such an individual must be giving the opportunity to present his own side of the matter before the tribunal. This ambit of fair hearing envisages an instance of adequately informing the person summoned before the tribunal, of the case against him; give him/her ample chance to correct or contradict the accusation(s) against him/her; afford the person the opportunity to challenge the evidence against him; and an opportunity to fairly state his own case at the hearing. ${ }^{11}$

It denotes basic fairness and it is a canon of natural justice. It is the duty of anyone in control of proceedings to allow both parties to be heard and should listen to the points of view of each. Even God, as reported by the scripture, saw Adam eat of the forbidden fruit, which He warned him (Adam) never to eat but the Lord still gave Adam affair hearing when the Lord asked, 'did you eat the fruit I told you not to eat?' 12 It was after Adam was unable to give a satisfactory answer that God pronounced punishment. That was the beginning of fair hearing. ${ }^{13}$

The cases that follow show that failure of the administrative tribunal to adhere to this tenets or principle of fair hearing leads to the regular court setting aside such decision by way of certiorari.

In Federal Civil Service Commission v Laoye, ${ }^{14}$ the respondent was employed as an executive officer (accounts) in September 1964. At a time during his years of service, he worked at the Consulate General Office in the Nigerian Embassy in New York. On his return to Lagos, the Ministry of External Affairs queried him twice over allegations which included that he colluded with some persons to defraud the Federal Government. Mr. Laoye cleared himself, denied the allegations and challenged his accusers to prove them. Unfortunately, in 1981, the Federal Civil Service Commission dismissed him. The Supreme Court held, upholding the quashing of Mr. Laoye's dismissal, that the Court's inclination towards fair hearing is strong, hard and solid. The duty of the court is to protect the rights of the individual in a democratic society governed by rule of law. It is consequently well settled that the decision reached thereby will be set aside. Thus, the $1^{\text {st }}$ appellant is a creature of the Constitution and is subject to it, and is thereby bound by the provisions of section 33 (1) of the 1979 Constitution, ${ }^{15}$ which has incorporated the common law fundamental rules of audi alterem pertem.

111999 Constitution of Nigeria, s. 36 generally.

12 Genesis 3:11.

13 Federal Civil Service Commission v Laoye [1989] 2 NWLR (pt.106) p.652.

14 Supra.

15 Now s. 36 (1) of the 1999 Constitution of Nigeria. 
In Olaniyan \& Ors $v$ University of Lagos \& Anor, ${ }^{16}$ the University of Lagos Council acted on the visitation report and the comments of the Visitor and terminated the appointment of the plaintiffs/appellants without giving them the opportunity to make representation nor to be heard. The Supreme Court held that the Council had not followed the legal principle of audi alterem pertem. Thus, the decision of the Council terminating the appointment of the plaintiffs/appellants Professor was quashed and they were reinstated in their respective positions.

More interesting is the case of Judicial Service Commission of Cross Rivers State v Young, ${ }^{17}$ where the respondent as the Chief Registrar of Cross Rivers State, was by an order of the court appointed the Receiver of the estate of one Chief Effiom Okon Effiom, who died intestate. Following a friction between the respondent and the Chief Judge of Cross Rivers State over the management and administration of the proceeds of the said estate, the respondent was redeployed from her office as the Chief Registrar to Head, Department of Planning, Research and Statistics, which posting the respondent rejected, even though she still maintained the same salary grade Level 17 which she held as the Chief Registrar. The respondent refused to resume to her new office but rather petition the Chief Justice of the Federation, accusing the Chief Judge of abuse of office, fraud, etc. Though she withdrew the said petition, she was suspended and retired from the Cross Rivers State Judicial Service Commission without trial. Consequently, the respondent took out an application at the High Court of Calabar for an Order of certiorari to quash the proceedings and decision of the Judicial Service Commission retiring her from the service. Quashing the decision of the Judicial Service Commission, and reinstating the respondent, the Supreme Court held, inter alia:

...it follows therefore that when an administrative or domestic tribunal is to determine whether an office is guilty of misconduct or of a breach of the regulations, then a "lis inter partes" arises and so thrown up the necessity for hearing before deciding and in such a case, the administrative body is acting judicially and the principle of fair hearing binding on judicial bodies would by same token bind such administrative body.

On the attributes of the principle of fair hearing in administrative proceedings, the court citing the case of BABA v N.C.A.T. $C^{18}$ observed that:

In a judicial or quasi-judicial body, a hearing in order to be fair must include the right of the person to be affected, i) to be present

16 [1985] 2 NWLR (Pt. 9) 599.

17 [2013] 11 NWLR (Pt. 1364) 1.

18 [1991] 5 NWLR (pt.192) 388 at 423, per Nnaemeka-Agu, J.S.C. 
all through the proceeding and hear all the evidence against him; ii) to cross examine or otherwise contradict all the witnesses that testify against him; iii) to have read before him all the documents tendered in evidence at the hearing; iv) to have disclosed to him the nature of all relevant material evidence including documentary and real evidence; v) to know the case he has to meet at the hearing and have adequate opportunity to prepare for his defence; and vi) to give evidence by himself, call witnesses if he likes and make oral submission either personally or through counsel of his own choice.

Where any of these requirements is breached, the decision of the administrative tribunal must be quashed. In the Young's case ${ }^{19}$ the defence of the appellants that they sent queries to the Respondent and her answers were used to reach their conclusion was held to be:

An insult on the sensibilities of all rational minds as the respondent had her natural rights violated while being presented with a fiat accompli already pre-determined before the so called investigations and deliberations.

In the case of contract of employment, the position of the law is that where it's a mere master/servant relationship, no procedural protection is guaranteed and the servant is not entitled to fair hearing; unless the contract of employment specifically provides for fair hearing in disciplinary or such administrative adjudicatory proceeding, in which case parties must comply with same because parties are bound by the contract they willingly entered into. ${ }^{20}$ That notwithstanding, such employee's remedies may lie in damages for breach of contract. Since the Court cannot impose a willing employee on an unwilling employer, however, where it is a contract of employment with statutory flavour, the principle of fair hearing applies and the aggrieved employee maybe reinstated. ${ }^{21}$

\subsection{Nemo judex in causa sua: No One Should be a Judge in His Own Cause (The} Rule against Bias and Interest)

This is the second principle of fair hearing. Under this rule, an administrative adjudicator who has any interest, howsoever in the matter before it must disqualify himself, ${ }^{22}$ else any decision taken by such tribunal will be quashed for want of fair trial at the instance of the party who protests against such alleged partial adjudicator.

9 Supra.

20 Egharevba v Osagie (2009) 40 NSCQR 469

21 Federal Civil Service Commission v Laoye (supra); Judicial Service Commission of Cross Rivers State v. Young (supra).

22 Atsegbua, op cit, p.139. 
The rules against bias doesn't only play out where an adjudicator manifestly has interest in the matter, it also plays out where either of the adjudicator is related to any of the parties to the dispute, or somehow affected, connected or concern with the subject-matter of the dispute, so as to raise doubts as to the impartiality of the tribunal bring about reasonable suspicion or real likelihood of bias.

In Tamti $v$ Nigerian Customs Service Board, ${ }^{23}$ the appellant appeared before the management meeting in which the decision to retire him on grounds of service misconducts and dereliction of duty was reached. The prosecutor, who prosecuted his case, remained behind with the members of the management committee when the appellant was asked to leave so that the Committee can make a decision. On the above findings, the court came to the conclusion that:

This singular act therefore of the prosecutors remaining behind in the room and thereafter, an adverse decision was given against the appellant creates suspicion that there has been an improper interference with the course of justice; it thus creates shadow of bias in the panel. This no doubt offends the $2^{\text {nd }}$ arm of the twin pillars of natural justice, nemo judex in causa sua. The prosecutors being a judge in its own case.

Consequently, the decision of the panel was set aside.

In Garba \& Ors. v University of Maiduguri ${ }^{24}$ the students of the University of Maiduguri went on rampage during a students' unrest. They destroyed various properties and burnt the house of the Deputy Vice Chancellor (DVC). The management of the University set up a disciplinary investigating board to probe the students' unrest. The DVC whose house was burnt down was made the chairman of the Board. Following the board's findings and recommendations, some students were expelled. They went to the court contending that their right to fair hearing has been breached by the board. The Supreme Court in upholding their claim, held inter alia, that since the chairman of the board which tried the appellants was the same DVC who himself was a victim of the rampage, there was a real likelihood of bias. Consequently, the students were reinstated.

Also, in Legal Practitioners Disciplinary Committee $v$ Fawehinmi, ${ }^{25}$ Chief Gani Fawehinmi succeeded in getting the court to stay proceedings of the Legal Practitioners Disciplinary Committee, which was to try him for professional misconduct in the nature of "Advertising, Touting and Publicity." The reason being that the Office of the Attorney-

23 [2009] 7 NWLR (Pt.1141) 636 CA.

24 [1986] 1 NWLR (Pt.18) 550.

25 [1985] NWLR (Pt.7) 300. 
General of the Federation appeared to be the complainant, prosecutor and the judge in the same matters. The Court in disqualifying the Disciplinary Committee, as constituted, from trying Chief Fawehinmi for professional misconduct, held that:

...not only must the LPDC not be bias against a legal practitioner whose conduct is being questioned, but also it must not place itself in a position in which it may appear that there is a real likelihood of bias.

From the foregoing, the Courts have established that, where there is any such likelihood or reasonable suspicion of bias, the decision of such a panel must be set aside or the panel must be disqualified where it is yet to start setting or taken a decision

\section{Allegation of Misconduct Touching on Crime}

One other interesting aspect of fair hearing is that aspect that prescribes that where the offence or misconduct for which an individual is brought before the administrative tribunal amounts to a crime under any written law in Nigeria, it is only a regular court that can try and convict on such crime, after which the administrative tribunal can then reach a decision based on the outcome of the criminal trial.

It can only be fair if such a such allegation touching on crime under any written law in Nigeria is tried by the regular court, hence, s. 36 (4) of the 1999 Constitution prescribed that:

Whenever any person is charged with a criminal offence, he shall, unless the charge is withdrawn, be entitled to fair hearing in public within a reasonable time by a court or tribunal.

Thus, in Garba v University of Maiduguri ${ }^{26}$ the Supreme held that:

...the offence for which the appellants were undoubtedly liable by the Board and the Panel included looting, arson, destruction of property and indecent assault. These are offences under the Penal Code and therefore are triable only by the regular courts of law.

26 Supra. 
The court went further by referencing the dictum of Fatayi-Williams, CJN in the case of Sofekun v. Akinyemi, ${ }^{27}$ where the then erudite CJN stated in clear terms the position of the law thus:

It seems to me that once a person is accused of a criminal offence he must be tried in a "court of law" where the complaints of his accusers can be ventilated in public and where he would be sure of getting a fair trial as set out in subsections (4) to (10) of section 22 of the Constitution of Nigeria. ${ }^{28}$ No tribunal, investigation panel, or committee will do. ${ }^{29}$

Also in F.C.S.C \& Ors $v$ Laoye $e^{30}$ the Supreme state the law in a clear and simple manner as that, '...if the allegation is one that touches the commission of a crime, it is only a Criminal Tribunal that could convict him.' And in Okocha v Civil Service Commission (Edo State) \& Anor ${ }^{31}$ the Court of Appeal making reference to both Garba's \& Laoye's case posited thus:

When a person is accused of committing a criminal offence, he must be taken before a court of law for trial and not merely by a disciplinary tribunal. By virtue of s. 33(1), (4) \& (13) of the 1979 Constitution, ${ }^{32}$ only a court of law or a judicial tribunal is competent to hear and determine a criminal charge against a person accused of committing a criminal offence.

However, it is a different set of rules where the person accused of a crime admits the commission of such crime. In such case, the administrative tribunal can proceed and dish sanctions for such admitted offence. ${ }^{33}$ Hence the Supreme Court went further in Laoye's $\operatorname{case}^{34}$ to clarify that:

...it is not so difficult where the person so accused accepts his involvement in the act complained of, and no proof of the criminal charge against him would be required. He has in such a case, been confronted with the accusation and he admitted it. $\mathrm{He}$ could face discipline thereafter.

27 (1980) 5-7 S.C., 1.

28 S. 33 (4) to (10) the time of the Garba's case, but now s. 36 (4) to (10).

29 At p.18.

30 Supra.

31 [2004] 3 NWLR (pt.861) 494.

32 Now s. 36 (1), (4) \& (13) the 1999 Constitution of Nigeria.

33 Okocha v. Civil Service Commission (Edo State) \& Anor (supra).

34 Supra. 
It must be emphasised that the principle that it is only a regular court that can try an allegation of misconduct touching on crime before an administrative tribunal will act on same is not applicable where such act of criminality is indicated as misconduct in the contract of employment. In such instance, the administrative tribunal can adjudicate on the matter and the employer can discipline the employee without recourse first to prosecution in a law court. ${ }^{35}$

4. Classification of Administrative Powers for the Purposes of Fair Hearing.

Conventionally, administrative powers are classified as Legislative, Executive or Administrative and Judicial or Quasi-Judicial. ${ }^{36}$ These classifications are not without any legal significance, especially as it relates to the application of the principles of natural justice.

Professor De Smith once observed that:

The manner of classifying the functions performed by the institutions of government is far more important than the manner of classifying the institutions themselves, and that the scope of judicial review of administrative actions, and the remedies available to persons aggrieved frequent depend upon the appropriate classification of the particular statutory function. ${ }^{37}$

For the purposes of fair hearing, where an administrative body's power is classified as legislative, executive/administrative, the principles of fair hearing do not apply, but if however, such power is classified as judicial/quasi-judicial; such body will be strictly bound by the principles of fair hearing. ${ }^{38}$

In Arzika v Governor of Northern Nigeria ${ }^{39}$ the applicant, Mallam Arzika sought the remedies of, inter alia, certiorari to quash the Order of the Governor removing him as District Head, and prohibition restraining the Governor from further exercising such powers. The Court held that the governor in making the said Order was acting administratively and not judicially, hence fair hearing does not apply and consequently, certiorari does not lie.

In Nwaoboshi \& Ors. v Military Governor of Delta State \& Ors., ${ }^{40}$ the Supreme Court supremely observed that:

35 Yusufv Union Bank of Nigeria Ltd. (1996) 6 NWLR (Pt. 457) 632.

36 Atsegbua, op cit, pp. 26-29.

37 Quoted in Atsegbua, op cit, p. 26.

38 Ibid, pp. 29-30.

39 (1961) All N.L.R. 379.

40 [2003] 11 NWLR (pt.831) 305; (2003) 5 S.C. 120. 
No legislative or executive act is subject to the controlling jurisdiction of the writ of certiorari on ground that it was not an act performed judicially... and a legislative or executive act cannot by rational thinking come within acts which are to be performed judicially.

The case of Judicial Service Commission of Cross Rivers State v. Young ${ }^{41}$ provides a clear illustration of the attitude of the courts toward classification of administrative powers. At the trial court and the court of Appeal, the courts erroneously held that the Judicial Service Commission was acting administratively; hence Mrs. Young was not entitled to fair hearing. The Supreme Court in reversing the rulings of the lower courts held that the Commission was acting quasi-judicially being an investigative disciplinary panel, hence bound by the principles of fair hearing.

Though there has been this ragging argument as to when a body could be said to be acting judicially or administratively, but a presumption has now evolved that whenever any power is conferred by any statute on any authority or body to make a determination on rights and obligations of individuals, such a determining power shall be exercised judicially and in accordance with the rules of natural justice. ${ }^{42}$ Therefore, a breach or otherwise of fair hearing is regards or treated as very fundamental and a sine qua non to any proceedings, hearing or a trial which is subject to an adjudicatory process. ${ }^{43}$ As noted by the Supreme Court in Legal Practitioners Disciplinary Committee v Fawehinmi, ${ }^{44}$

The debate over what constitutes a judicial tribunal, quasijudicial tribunal, a domestic tribunal, a tribunal simpliciter, arbitrament, forum conpotens, etc, will certainly go on as an academic exercise; but once a body of person of persons by whatever name called, are invested with the authority to hear and determine particular issues, or disputes either by consent of the disputants, or by an order of court, or by the provision of the statute, such a body will be required to carry out its function with that fairness and impartiality, which the rules of natural justice dictate. $^{45}$

\section{Conclusion}

Following the rise in the functions of administrative authorities, the need for administrative adjudication has not only become desirable, but inevitable. Not minding

41 Supra.

42 Ridge v Baldwin (supra).

43 Tamti v. Nigerian Custom Service Board (supra).

44 Supra.

45 Per Oputa, J.S.C. at p. 387. 
that these tribunals are bound by the principles of fair hearing, some of their attributes threatens the individual's right to fair hearing. This paper has painstakingly, examined and stated the law in Nigeria as regards the extent of applicability of the principles of natural justice (fair fairing) in administrative adjudication.

It is the view of this paper that administrative adjudicatory bodies are compulsorily bound by the principles of fair hearing as most of their functions affect the rights and obligations of individuals appearing before them. These principles are however not straight jacket principles, hence the expositions and the discussion that form the fulcrum of this paper.

\section{Recommendations}

Considering the importance and imperative for the observance of the principles of fair hearing by administrative adjudicatory bodies and flowing from the discussions, observations and analysis of the principles in this paper, it is recommended that:

\section{- Clear Legal Procedure}

One of the banes of administrative adjudication is that most administrative panels and tribunals do not observe the principles of fair hearing. As this paper exposed through some of the cases it reviewed, administrative tribunal/panel hardly observe principles of natural justice, especially the audi alteram partem rule. Individuals are hardly heard before a decision is reached on their matters. And where there are laydown procedure, administrative tribunals fail to observe there legal procedures aim at guaranteeing human rights. To checkmate this unpleasant trend, administrative adjudicatory body should have clear and unambiguous legal procedure to regulate their proceedings. Such legal procedure should highlight and emphasise the principles of natural justice (fair hearing) and mandate the panel to strictly observe same.

\section{- Expertise}

In most, if not all administrative tribunals, members of the panel lack the basic legal knowledge to appreciate what fair hearing is all about, not to talk of according a party fair hearing. Granted that one cannot literally give what he does not have, it became common place these administrative tribunals hardly adhere to the tenets of fair hearing. Little wonders then their decisions are often challenged and set aside by the courts. It therefore becomes necessary that members (or at least one member) of administrative adjudicatory panels/tribunals must have a good or fair knowledge of law and the concept of human right (most especially, right to fair hearing).

\section{- Adequate Opportunity and Facility for Defence}

It is commonplace that these administrative tribunals set a time frame to conduct their proceedings, not minding, at times, that such time frame might not be sufficient for the preparation and presentation of a party's defence contrary to the stipulation of "a 
reasonable time" prescribed by s. 36 (1) \& (6) (b) of the 1999 Constitution of Nigeria. Where the opportunity is denied, it most often results in denial of fair hearing. It is therefore recommended that as part of the requirement for legal procedure, individual appearing before administrative tribunals/panels should be afforded adequate opportunity to prepare and present their case/defence to any allegation of any malfeasance against them.

Another of such denial of opportunity to prepare one's defence presents itself in the form of disregards of the right to counsel of one's choice by administrative tribunals/panels. ${ }^{46}$ Administrative tribunals often if not always, deny individuals appearing before it of their right to a legal practitioner of their choice contrary to s. 36 (6) (c) \& (d) of the 1999 Constitution of Nigeria. It is also recommended that as part of the legal procedure and guidelines for settings of administrative adjudicatory bodies, there should be the mandatory requirement that individual appearing before such panel should elect to exercise their right to counsel of their choice. This is necessary to allow for the counsel to ensure the administrative adjudicatory body does not deny such individual of the right to fair hearing and other rights the individual might be entitled to.

\section{- Mandatory Public Hearing}

Most administrative adjudicatory proceeding are held in secret contrary to the provisions of s.36 (3) \& (4) of the 1999 Constitution of Nigeria, which prescribe that such proceedings be held in public as part of ensuring that the parties' rights to fair trial are not denied them. It is thus recommended that the legal procedure and guidelines for the proceedings of administrative panels should stipulate that such proceedings must be held in public, unless the situation is such that the proceedings should be held in camera.

\section{- Enlightenment and Reorientation}

Administrative tribunals are often nothing but a tool of the authority that set them up to achieve a "witch hunting" purpose. They are usually misused and abused by the appointing authority in persecuting targeted individuals. ${ }^{47}$ There is therefore the need for enlightenment and reorientation. Those who are appointed into administrative adjudicatory panels/tribunals are to be enlightened that they have a legal obligation to ensure that the justice of the case is met. They are also to be educated of the rights of the individuals appearing before them.

46 Abiola v FRN [1997] 2 NWLR (pt.488) p. 439.

47 Judicial Service Commission of Cross Rivers State v Young (supra); Obot v CBN [1993] 8 NWLR (pt.310) p. 140; Aiyetan v NIFOR [1987] 3 NWLR (pt.59) p. 48 